\title{
Pembudidayaan dan Pembuatan Teh Daun Binahong untuk Mengobati Penyakit Asam Urat
}

\author{
Cultivation and Production of Binahong Leaf Tea to Treat Gout
}

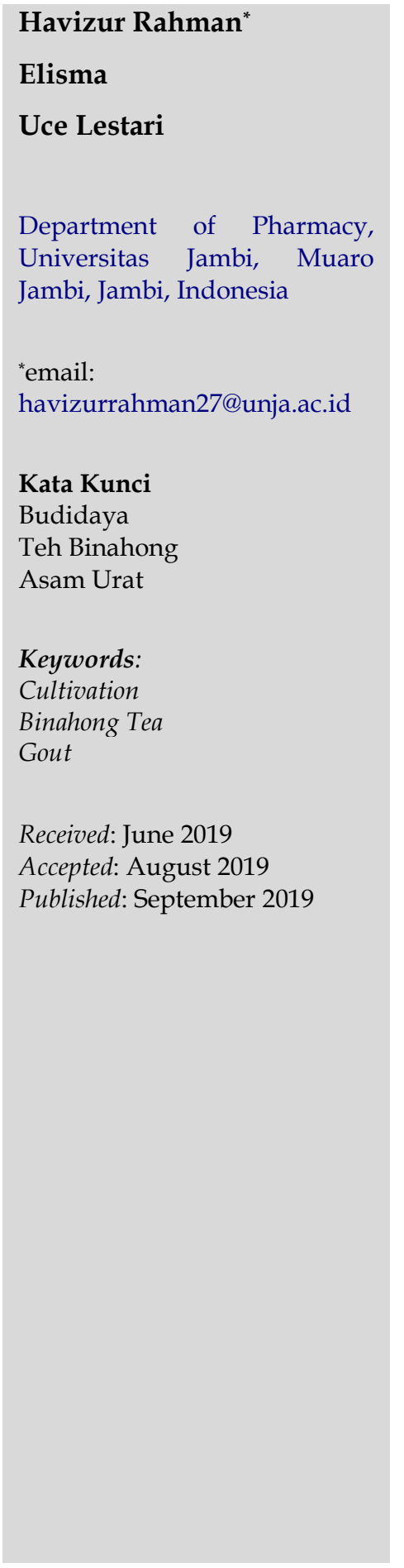

\begin{abstract}
Abstrak
Program pengabdian masyarakat ini bertujuan memperkenalkan binahong, manfaatnya mengatasi asam urat serta cara membudidayakannya. Selain itu masyarakat diberi keterampilan cara membuat teh daun binahong sehingga pemanfaatan untuk mengatasi asam urat menjadi lebih praktis, takaran terukur sehingga tujuan terapi tercapai. Penyakit asam urat merupakan salah satu bentuk artritis yang sering dikaitkan dengan sendi kemerahan, bengkak, panas dan kaku. Prevalensi penyakit asam urat dari tahun ke tahun semakin meningkat. Pria mempunyai resiko penyakit asam urat yang lebih tinggi dibanding wanita. Upaya masyarakat dalam mengobati penyakit asam urat menggunakan obat kimia terbukti menimbulkan efek samping yang serius. Penggunaan obat herbal dapat dijadikan terapi pendamping maupun sebagai alternative terapi dalam menanggulangi penyakit tersebut. Binahong secara empiris telah banyak digunakan untuk mengatasi berbagai macam penyakit. Salah satunya adalah penyakit asam urat. Pemanfaatan tanaman ini dalam terapi pendukung penyakit asam urat sangatlah penting karena hasil penelitian tanaman ini mempunyai banyak khasiat dengan toksisitas minimal. Metode yang digunakan pada pengabdian ini dengan memberikan penyuluhan dan pelatihan. Hasil evaluasi pelaksanaan pembudidayaan dan pembuatan teh binahong dapat terlihat bahwa peserta yang hadir dalam pengabdian masyarakat Pembudidayaan dan Pembuatan Teh Daun Binahong untuk Pengobatan Penyakit Asam Urat sebanyak 29 orang warga RT 02 Desa Mendalo Indah Jambi Luar Kota dan setelah dilakukan pengabdian ini masyarakat telah mengetahui gejala penyakit asam urat, manfaat binahong sebagai pengobatan penyakit asam urat serta mengetahui cara budidaya binahong untuk pengobatan maupun wadah peningkatan ekonomi warga.
\end{abstract}

\begin{abstract}
The community service program aims to introduce binahong plants, and its benefits to overcome gout and how to cultivate. The community will be given the skill of how to make binahong leaf tea so that utilization of binahong leaves to overcome gout become more practical, right doses so the goal of therapy for gout can be achieved. Gout is one form of arthritis that is often associated with reddish, swollen, hot and stiff joints. The prevalence of gout from the year is increasing. Men have a higher risk of gout than women. Community efforts in treating gout using chemical drugs have been shown to cause serious side effects. The use of herbal medicine can be used as an alternative therapy in dealing with this disease. The binahong plant is an empirically widely used plant to treat various illness. One of them is gout. The use of this plant in gout support therapy is essential because, from the research result, this plant has many properties with minimal toxicity. The method used in this service is by providing counselling and training. The results of evaluating the implementation of cultivation and making of binahong leaf tea for the treatment of gout, many as 29 residents of RT 02 Mendalo Indah Jambi, Luar Kota Village. The benefits of binahong as a treatment for gout as well as residents also know how to cultivate binahong for self-treatment and economic improvement container of the citizens.
\end{abstract}




\section{PENDAHULUAN}

Penyakit gout atau lebih dikenal dengan istilah asam urat merupakan salah satu bentuk artritis yang sering dikaitkan dengan sendi kemerahan, bengkak, panas dan kaku. Salah satu resiko penyakit ini adalah tingginya kadar asam urat dalam darah (Milind et al., 2013). Hiperurisemia adalah keadaan terjadinya peningkatan kadar asam urat darah di atas normal lebih dari 7 $\mathrm{mg} / \mathrm{dL}$. Hiperurisemia dapat disebabkan karena peningkatan metabolisme asam urat, penurunan eksresinya melalui urin, atau kombinasi keduanya (Benn et al., 2018; Putra, 2006).

Asam urat merupakan hasil akhir dari metabolisme purin, suatu produk sisa yang tidak mempunyai peran fisiologi. Asam urat yang terbentuk setiap hari dibuang melalui saluran pencernaan atau ginjal. Pada kondisi patofisiologis dapat terjadi peningkatan kadar asam urat dalam darah melewati batas normal yang disebut dengan hiperurisemia (Widyanto, 2014; Bobulescu \& Moe, 2012). Hiperurisemia merupakan kondisi dengan peningkatan konsentrasi asam urat di atas normal (Hawkins \& Rahn, 2005). Pada hiperurisemia dapat terjadi akumulasi kristal asam urat pada persendian sehingga menimbulkan rasa sakit atau nyeri yang dikenal dengan istilah gout (Fitrya \& Muharni, 2014).

Terapi penyakit sendi pada hakikatnya bertujuan untuk menghilangkan rasa nyeri dan kekakuan, menghentikan serangan, menjaga atau meningkatkan mobilitas sendi, membatasi kerusakan fungsi dan mengurangi faktor penyebab, sedangkan sasaran dari terapi ini adalah mempertahankan dan meningkatkan kualitas hidup. Terapi ini dapat berupa terapi farmakologi (dengan pemberian obat) dan penatalaksanaan dengan non obat berupa latihan fisik ringan dan diet makanan (Kim et al., 2017; Hawkins \& Rahn, 2005)

Tumbuhan merupakan sumber bahan alam yang banyak manfaatnya sebagai bahan obat. Timbulnya kesadaran masyarakat tentang dampak negatif obatobatan berbahan kimia membuat masyarakat mulai kembali ke pengobatan dengan menggunakan obat tradisional yang berkhasiat sebagai obat untuk mengobati berbagai macam penyakit (Ekor, 2013). Salah satu tanaman yang memiliki banyak khasiat dalam mengobati penyakit ialah binahong (Anredera cordifolia (Ten.) Steenis).

Pada proses skrining fitokimia daun binahong diketahui mengandung flavonoid, saponin, steroid/triterpenoid dan kumarin (Djamil et al., 2012). Hampir semua bagian tanaman binahong ini dapat dimanfaatkan mulai dari batang, akar, bunga, dan daun. Bagian yang sering dimanfaatkan untuk kesehatan atau sebagai obat herbal adalah daunnya (Manoi, 2009). Secara empiris daun binahong dimanfaatkan untuk mengobati rasa nyeri, maag, sariawan, meningkatkan stamina, melancarkan peredaran darah dan asam urat. Selain itu, binahong mampu meningkatkan vitalitas pria, mengatasi pembengkakan dan pembekuan darah, memulihkan kondisi lemah, menyembuhkan luka, mengobati diabetes mellitus, menurunkan kolesterol dan asam urat (Shabella, 2012; Guo \& Di Pietro, 2010).

Prevalensi penyakit asam urat dari tahun ke tahun semakin meningkat. Pria mempunyai resiko penyakit asam urat yang lebih tinggi dibanding wanita. Upaya masyarakat dalam mengobati penyakit asam urat menggunakan obat kimia terbukti menimbulkan efek samping yang serius akibat penggunaan obat kimia dalam jangka waktu yang lama. Obat-obatan yang sering digunakan mempunyai dampak terhadap gangguan lambung, kerapuhan tulang dan hipertensi (Nurhamidah \& Nofiani, 2015).

Penggunaan obat herbal dapat dijadikan terapi pendamping maupun sebagai alternatif terapi dalam menanggulangi penyakit asam urat (Sinaga et al., 2014). Tanaman binahong merupakan tanaman yang secara 
empiris telah banyak digunakan untuk mengatasi berbagai macam penyakit. Salah satunya adalah penyakit asam urat. Pemanfaatan tanaman ini dalam terapi pendukung penyakit asam urat sangatlah penting karena dari hasil penelitianpun tanaman ini mempunyai banyak khasiat dengan toksisitas minimal sehingga perlu diperkenalkan kepada masyarakat (Fitriyah et al., 2013).

Pengabdian ini dilaksanakan di RT 02 desa Mendalo Indah kecamatan Jambi Luar Kota. Desa Mendalo Indah yang termasuk dalam kecamatan Jambi luar Kota Kab. Muaro Jambi, yang merupakan desa hasil pemekaran dari Desa Mendalo Darat. Desa ini mempunyai 12 rukun tetangga. Sedangkan RT 02 pada desa ini mempunyai jumlah 85 kepala keluarga dengan jumlah penduduk lebih kurang 350 orang. Sebagian besar masyarakat Desa Mendalo Indah bermata pencaharian sebagai petani, buruh, pedagang dan pegawai. Desa Mendalo Indah letaknya berdekatan dengan kampus Universitas Jambi. Sebelah utara Desa Mendalo Indah berbatasan dengan desa Mendalo Laut, selatan dengan desa Pematang Gajah, timur dengan desa Mendalo Darat dan sebelah barat berbatasan dengan Desa Simpang Sungai Duren dan Pijoan.

Program pengabdian masyarakat ini bertujuan untuk memperkenalkan tanaman binahong, manfaatnya untuk mengatasi asam urat serta bagaimana cara membudidayakannya. Selain itu masyarakat diberi keterampilan bagaimana cara membuat teh daun binahong sehingga pemanfaatan daun binahong untuk mengatasi asam urat menjadi lebih praktis, takarannya juga terukur sehingga tujuan terapi penyakit asam urat dapat tercapai.

\section{METODOLOGI}

Pelaksanaan program pengabdian kepada masyarakat ini meliputi penyuluhan tentang pengenalan penyakit asam urat, cara budidaya dan manfaat, nilai ekonomi dari budidaya binahong, serta pembuatan teh herbal binahong dan evaluasi kegiatan. Kemudian diiringi dengan pemeriksaan cek kesehatan gratis yang meliputi pemeriksaan kadar asam urat yang digunakan sebagai indikasi adanya gejala gout.

Masyarakat RT 02 Kel. Mendalo Indah diberikan pengetahuan mengenai penyakit asam urat, gejala, faktor resiko penyebabnya dan cara pencegahannya. Selain itu disampaikan cara pengobatan penyakit ini. Cara pengobatannya meliputi pemberian obat, terapi non obat salah satunya nya dengan diet makanan dan latihan fisik ringan. Selain itu diuraikan manfaat tanaman binahong salah satunya menurunkan asam urat. Diharapkan masyarakat dapat mengetahui tentang penyakit asam urat, penyebabnya, gejalanya dan cara pengobatannya. Kegiatan ini diharapkan dapat memberikan informasi dan memberdayakan masyarakat yang terkena asam urat untuk melakukan latihan fisik ringan yang benar, mengkonsumsi obat dengan benar dan mengetahui cara pengobatan non obat, bagaimana cara latihan fisik ringan untuk meredakan nyeri yang ditimbulkan asam urat serta makanan yang dapat menyebabkan tingginya konsentrasi asam urat dalam tubuh.

Masyarakat diperkenalkan bentuk morfologi tanaman binahong, cara menanamnya dan bagaimana cara membudidayakannya. Masyarakat diberi keterampilan bagaimana cara membuat teh herbal binahong yang lebih praktis digunakan. Kegiatan ini bertujuan agar masyarakat dapat diberdayakan memanfaatkan tanaman ini untuk mengobati penyakit asam urat dan dapat dijadikan peluang bisnis membantu perekonomian keluarga

Solusi yang ditawarkan dalam kegiatan program pengabdian kepada masyarakat (PPM) ini adalah pemberdayaan masyarakat RT 02 Mendalo Indah dalam 
memahami penyakit asam urat dan dapat mempunyai keterampilan dalam penatalaksanaan asam urat menggunakan obat herbal ataupun dengan terapi non obat. Selain itu kegiatan ini dapat memberdayakan masyarakat dalam pembuatan teh herbal binahong yang berkhasiat menurunkan asam urat. Tujuan pembuatan teh herbal ini adalah agar penggunaannya lebih praktis dan dapat dijadikan peluang bisnis dalam membantu perekonomian masyarakat.

\section{HASIL DAN PEMBAHASAN}

Pengenalan Binahong

Kegiatan pengabdian masyarakat dimulai dari koordinasi dengan ketua RT 02 Desa Mendalo Indah Jambi Luar Kota untuk menentukan waktu dan tempat pelaksanaan kegiatan Budidaya dan pembuatan teh binahong Untuk Mengobati Penyakit Asam Urat sebagai obat alternative atau pendukung pengobatan asam urat. Tim PPM juga meminta ijin kepada lurah desa setempat untuk pelaksanaan kegiatan tersebut.

Pelaksanaan kegiatan penyuluhann tentang penyakit asam urat, cara pengobatan, khususnya dengan menggunakan bahan obat yang berasal dari tanaman dalam hal ini tanaman binahong. Selanjutnya dijelaskan cara pemakaian daun binahong itu sendiri sebagai pengobatan asam urat, cara pembuatan teh binahong serta cara bercocok tanam tanaman binahong. Acara ini dihadiri oleh ibu-ibu dan bapak-bapak dari RT 02 Desa Mendalo Indah Jambi Luar Kota. Pelaksanaan acara ini dilaksanakan di rumah ketua RT 02 Desa Mendalo Indah dan bertujuan agar masyarakat RT 02 Desa Mendalo Indah mengenal tanaman binahong, manfaat dan cara budidaya dari binahong. Dokumentasi kegiatan pengenalan binahong kepada peserta disajikan pada Gambar 1 sampai 3.

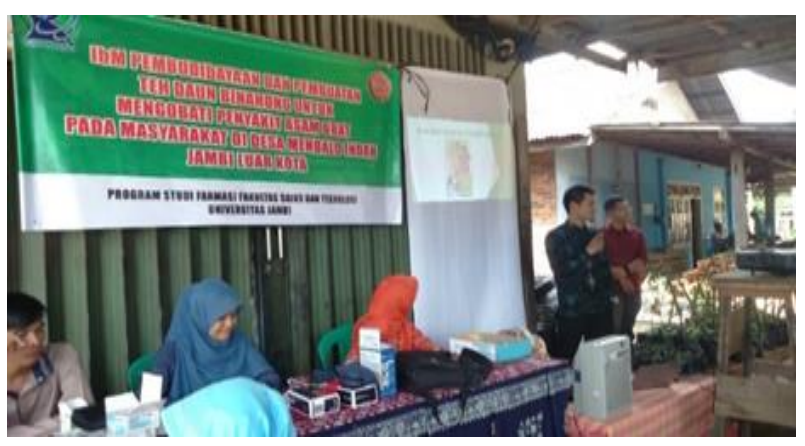

Gambar 1. Narasumber menyampaikan materi tentang binahong

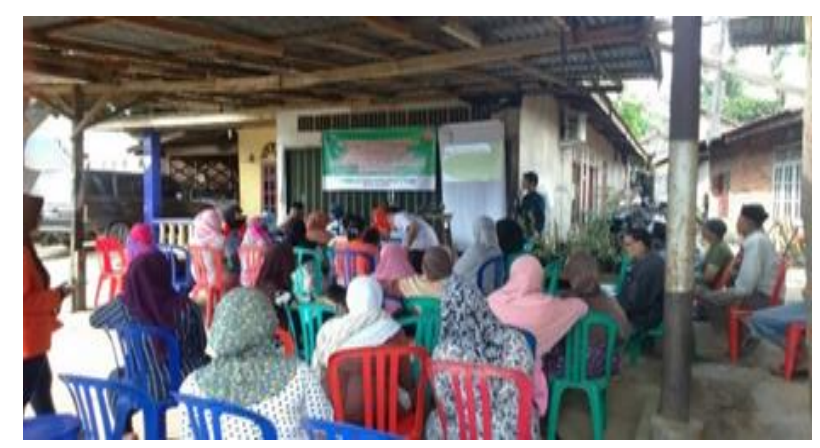

Gambar 2. Penyuluhan asam urat dan budidaya binahong

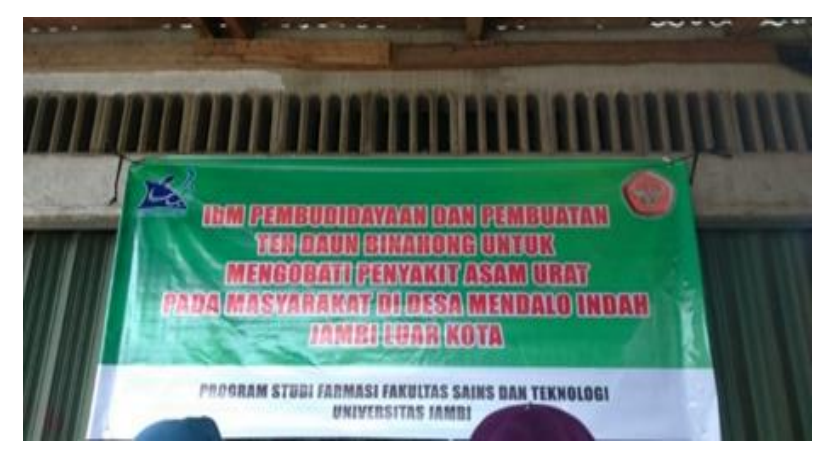

Gambar 3. Spanduk kegiatan pengabdian

Budidaya Binahong

Sebelumnya tim PPM telah membudidayakan tanaman ini sebelum diperkenalkan kepada masyarakat nantinya. Setelah tanaman binahong cukup besar atau siap panen, kemudian baru tim melaksanakan acara pengabdian masyarakat. Dalam acara ini tim pengabdian masyarakat menjelaskan cara budidaya tanaman binahong, serta memberikan beberapa tanaman binahong yang siap untuk digunakan. Pemberian informasi budidaya binahong yang dihadiri oleh Ibu-ibu dan Bapak-bapak 
RT 02 Desa Mendalo Indah Jambi Luar Kota. Budidaya binahong dilaksanakan dengan cara sebagai berikut:

1. Persiapan media tanam dan pembibitan umbi binahong

a. Pembuatan sekam arang

b. Penyiapan tanah untuk media tanam

c. Penyiapan kotoran ayam

d. Penyiraman tanah yang telah tercampur dengan kotoran ayam agar tidak berdebu

e. Tanah dan kotoran ayam yang telah disiram dicampur dengan sekam arang

f. Pencampuran semua komponen

g. Media tanam yang telah jadi dimasukkan kedalam polybag

Dokumentasi persiapan media tanam disajikan pada Gambar 4 dan 5 .

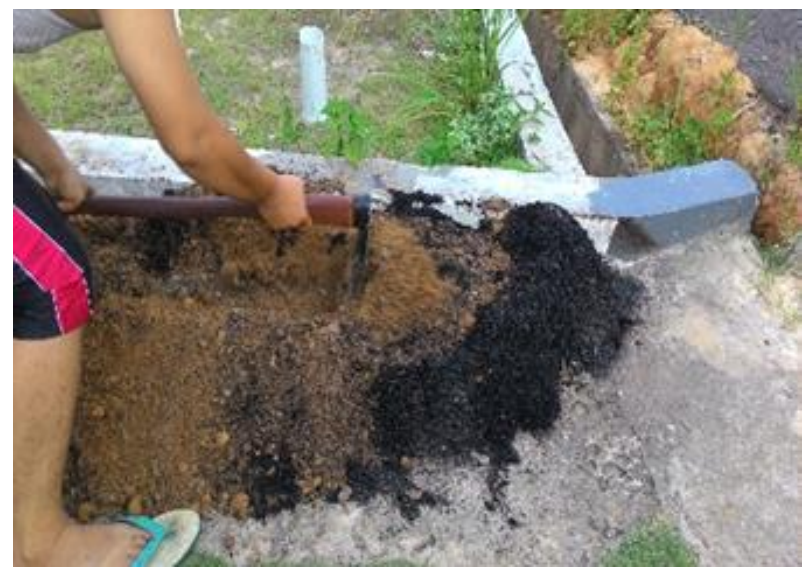

Gambar 4. Pencampuran media tanam

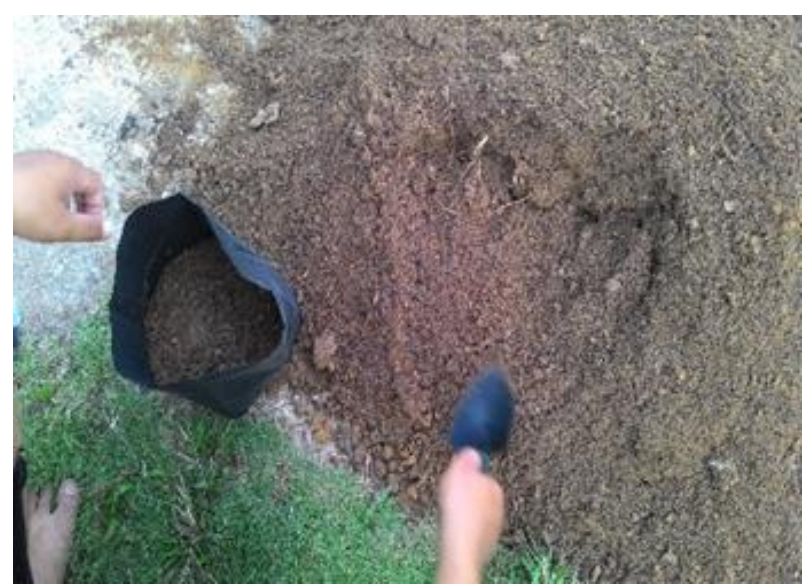

Gambar 5. Pemindahan media tanam ke dalam polybag
2. Penanaman bibit binahong

a. Bibit binahong disemai

b. Hasil persemaian dipindahkan kedalam polybag baru yang telah diiisi media tanam

c. Masing-masing polybag ditanami dengan satu bibit binahong

d. Bibit yang telah ditanami di polybag, dijaga kelembapan medianya agar bibit tumbuh optimal

e. Bibit yang sudah mulai tumbuh diberikan penyangga sebagai tempat merambat.

Dokumentasi penanaman bibit binahong disajikan pada Gambar 6 dan 7.

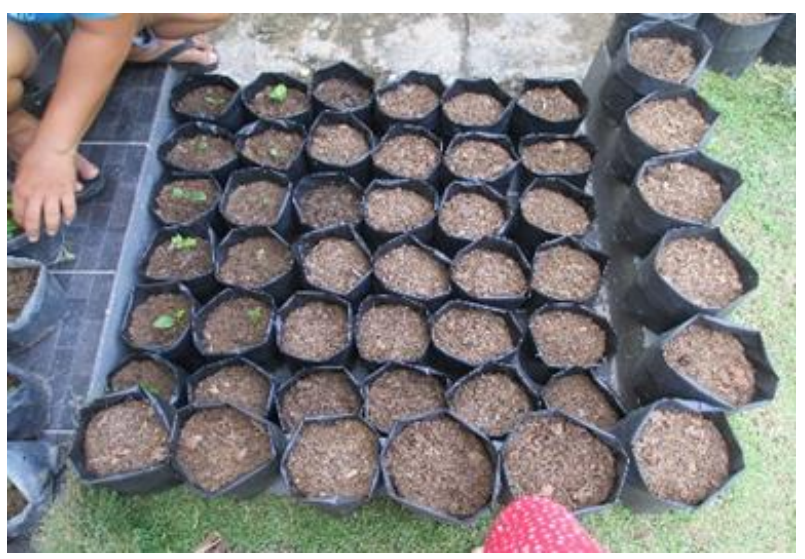

Gambar 6. Penyusunan polybag berisi media tanam

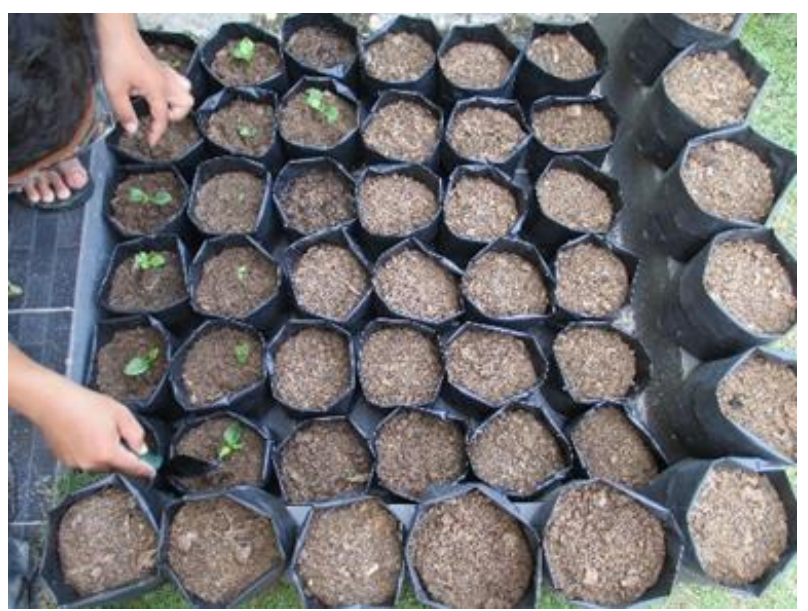

Gambar 7. Penanaman bibit binahong

\section{Pemeliharaan}

a. Tanaman dipupuk dua minggu sekali 
b. Dijaga kelembapannya, dengan menyiram

c. Apabila tanaman telah besar, bidang rambat hendaklah ditambah agar tanaman tidak menjalar di permukaan tanah.

d. Ketika pertumbuhan agar dijauhkan degan tanaman lain agar tidak menjalar.

Dokumentasi kegiatan pemeliharaan disajikan pada Gambar 8 dan 9.

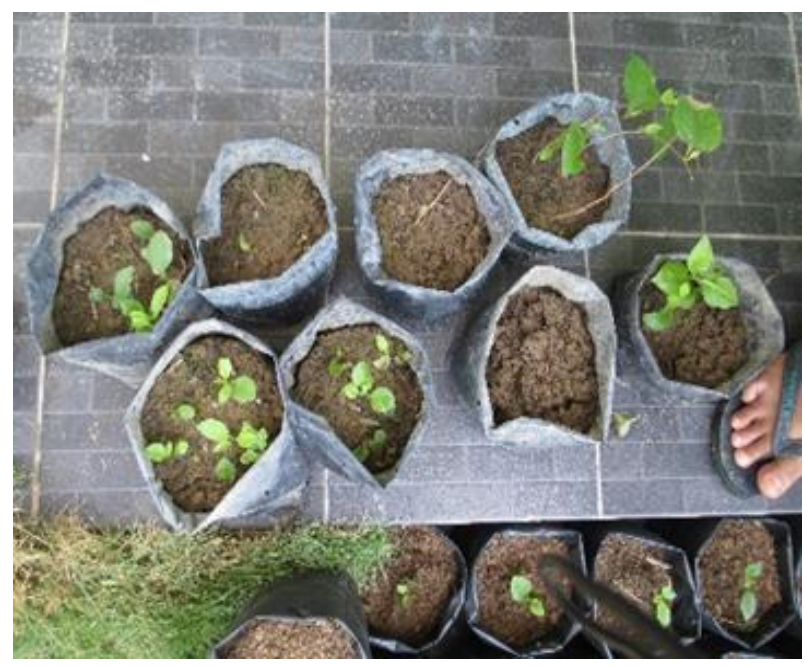

Gambar 8. Pengamatan pertumbuhan bibit binahong

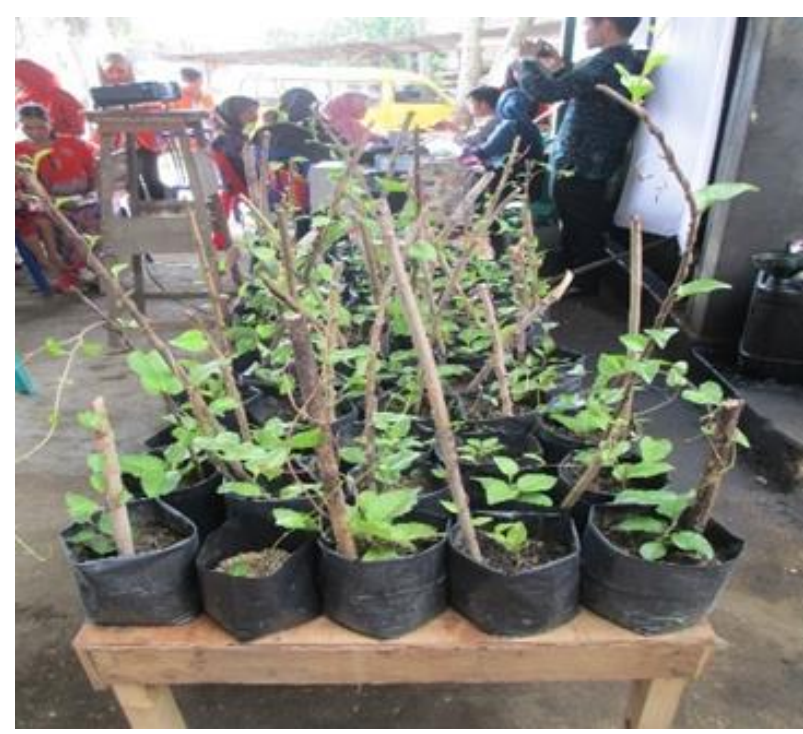

Gambar 8. Seluruh bibit binahong telah tumbuh

4. Pemanenan

Panen daun dapat dilakukan setelah daunnya telah melebar.

\section{KESIMPULAN}

Warga RT 02 Desa Mendalo Indah telah mengetahui gejala penyakit asam urat, manfaat binahong sebagai pengobatan penyakit asam urat dan selain itu warga juga telah mengetahui bagaimana cara budidaya binahong untuk pengobatan sendiri maupun wadah peningkatan ekonomi dari warga, artinya warga RT 02 Desa Mendalo Indah telah mendukung ketersediaan bahan baku obat asam urat di RT 02 Desa Mendalo Indah.

\section{UCAPAN TERIMA KASIH}

Program Pengabdian ini terlaksana atas dukungan pendanaan dari LPPM Universitas Jambi dengan dukungan dari Masyarakat Warga RT 02 Desa Mendalo Indah Jambi Luar Kota sebagai peserta kegiatan.

\section{REFERENSI}

Benn, C.L., Dua, P., Gurrell, R., Loudon, P., Pike, A., Storer, R.I., Vangjeli, C. 2018. Physiology of Hyperuricemia and Urate-Lowering Treatments. Frontiers in Medicine. 5:160. https://doi.org/10.3389/fmed.2018.00160

Bobulescu, I.A., Moe, O.W. 2012. Renal Transport of Uric Acid: Evolving Concepts and Uncertainties. Advances in Chronic Kidney Disease. 19(6):358371. https://dx.doi.org/10.1053/j.ackd.2012.07.00 9

Djamil, R., Wahyudi, P.S., Wahono, S., Hanafi, M. 2012. Antioxidant Activity of Flavonoid from Anredera cordifolia (Ten) Steenis Leaves. International Research Journal of Pharmacy. 3(9):241-243.

Ekor, M. 2013. The growing use of herbal medicines: issues relating to adverse reactions and challenges in monitoring safety. Frontiers in Pharmacology.

4:177. https://dx.doi.org/10.3389/fphar.2013.00177

Fitriyah, N., Purwa, M.K., Alfiyanto, M.A., Mulyadi, M., Wahyuningsih, N., Kismanto, J. 2013. Obat Herbal Antibakteri ala Tanaman Binahong. Jurnal Kesehatan Kusuma Husada. 4(2):116-122. 
Fitrya, F., Muharni, M. 2014. An Antihyperuricemia Effect of Ethanol Extract of Tunjuk Langit Rhizome (Helmynthostachys zaylanica Linn Hook) on Swiss Male Mice. Majalah Obat Tradisional. 19(1):14-18. https://doi.org/10.22146/tradmedj.8085

Guo, S., Di Pietro, L.A. 2010. Factors Affecting Wound Healing. Journal of Dental Research. 89(3):219229. https://dx.doi.org/10.1177/002203450935912 5

Hawkins, D. W., Rahn, D.W. 2005. Gout and Hyperuricemia: Pharmacotherapy a Pathophysiological Approach. New York: Mc Graw-Hill.

Kim, Y., Oh, H.C., Park, J.W., Kim, I.S., Kim, J.Y., Kim, K.C., Chae, D.S., Jo, W.L., Song, J.H. 2017. Diagnosis and Treatment of Inflammatory Joint Disease. Hip \& Pelvis. 29(4):211-222. https://dx.doi.org/10.5371/hp.2017.29.4.211

Manoi, F. 2009. Binahong (Anredera cordifolia) sebagai obat. Warta Penelitian dan Pengembangan Tanaman Industri. 15(1): 3-5.

Milind, P., Sushila, K., Neeraj, S. 2013. Understanding Gout Beyond Doubt. International Research Journal of Pharmacy. 4(9):25-34. http://doi.org/10.7897/2230-8407.04907

Nurhamidah, N., Nofiani, S. 2015. Faktor-Faktor yang Berhubungan dengan Kejadian Asam Urat pada Pasien Rawat Jalan di Rumah Sakit Stroke Nasional Bukittinggi Tahun 2015. Jurnal Kesehatan Perintis (Perintis's Health Journal). 2(2):1-13.

Putra, T.R. 2006. Hiperurisemia. In Sudoyo, A.W., Setiyohadi, B., Alwi, I., Simadibrata, M., Setiati, S. (Ed). Buku Ajar Ilmu Penyakit Dalam. Edisi Ke-4. Jakarta: Pusat Penerbitan Ilmu Penyakit Dalam FK UI.

Shabella, R. 2012. Terapi Daun Binahong. Cetakan ke-1. Klaten: Cable Book.

Sinaga, A.F., Bodhi, W., Lolo, W.A. 2014. Uji Efek Ekstrak Etanol Daun Salam (Syzygium polyanthum (Wight.) Walp) terhadap Penurunan Kadar Asam Urat Tikus Putih Jantan Galur Wistar (Rattus novergicus L.) yang Diinduksi Potasium Oksonat. Pharmacon. 3(2):141-145.
Widyanto, F.W. 2014. Artritis Gout dan Perkembangannya. Saintika Medika: Jurnal Ilmu Kesehatan dan Kedokteran Keluarga. 10(2):145152. https://doi.org/10.22219/sm.v10i2.4182 